$\begin{array}{lll}\text { KULTURA } & \begin{array}{l}\text { POLSKA A KADEMIA NAUK } \\ \text { KOMITET SOCJOLOGII }\end{array} & \text { ISSN 0023-5172 } \\ \text { i } & \begin{array}{l}\text { INSTYTUT STUDIÓW POLITYCZNYCH } \\ \text { SPOLCZENSTWO }\end{array} & \\ 2018, \text { nr } 2 & \text { PRZEMIANY WIĘZI }\end{array}$

EWA MICHNA

Uniwersytet Jagielloński

\title{
ŚLĄZACY MIĘDZY POLITYCZNĄ PODMIOTOWOŚCIĄ A POCZUCIEM UPRZEDMIOTOWIENIA
}

\begin{abstract}
„Jeśli ktoś chce mi narzucić swoją narodowość, inną kulturę, inny język, inne jakieś wartości. To dla mnie jest zniewolenie. Uważam, że każdy człowiek ma prawo do swoich rzekłbym, do swojego języka, do swojej kultury. Także nieuznawanie śląskości to jest jeszcze bardziej, jeszcze mocniej i dobitniej wskazuje na to, że nas się... że w ogóle my jesteśmy przedmiotem. Przedmiotem, którym się manipuluje".
\end{abstract}

Kamilla Dolińska

Przytoczony cytat z wywiadu, który znalazłam w książce Kamilli Dolińskiej Potoczny i ideologiczny poziom doświadczania ślaskości. Ślazacy w poszukiwaniu odrębności? (2009, s. 138; podkr. - E.M.), stał się inspiracją do napisania tego tekstu. Wypowiedź jednego z rozmówców wrocławskiej socjolożki pozwoliła mi dostrzec pewien istotny problem, który przewijał się także $\mathrm{w}$ moich rozmowach $z$ działaczami grup etnicznych, a wcześniej nie był przedmiotem mojej refleksji. Wróciłam zatem do zebranego materiału, aby zastanowić się, jakie są skutki braku prawnego uznania przez państwo polskie odrębności Ślązaków, z którymi borykają się działacze organizacji śląskich ${ }^{1}$.

Adres do korespondencji: ewa.michna@uj.edu.pl

${ }^{1}$ Podstawą przedstawionych analiz jest materiał empiryczny zebrany podczas badań terenowych prowadzonych przeze mnie na Górnym Śląsku od 2008 roku. Obejmuje on 80 wywiadów swobodnych $z$ działaczami organizacji śląskich walczących o uznanie przez państwo odrębności ich grupy. Przedmiotem rozmów były: szeroko rozumiana polityka tożsamości i strategie walki 


\section{OCHRONA MNIEJSZOŚCI — ASPEKTY PRAWNE}

Zagadnienie to nie było dotychczas przedmiotem zainteresowania badaczy procesów emancypacji etnicznej/narodowej Ślązaków. Wydaje się, że jednym $z$ powodów niedostrzegania konsekwencji braku prawnego uznania jest to, że problem stał się widoczny dopiero po uchwaleniu Ustawy $z$ dnia 6 stycznia 2005 roku o mniejszościach narodowych $i$ etnicznych oraz o jezzyku regionalnym. Wraz $z$ pojawieniem się tego dokumentu prawne uznanie zaczęło mieć realne znaczenie dla sposobu funkcjonowania wymienionych w niej czternastu podmiotów (mniejszości narodowych, etnicznych i grupy posługującej się językiem regionalnym). Ustawa wyznacza bowiem możliwości działania na rzecz zachowania i rozwoju kultury i etnicznej tożsamości objętych nią społeczności $-z$ wymienionych w niej czyni podmioty polityczne mogące skorzystać $z$ wielu przysługujących im praw.

Podjęta przeze mnie problematyka w szerszej perspektywie teoretycznej dotyka - dyskutowanej między innymi w socjologii, antropologii i filozofii społecznej - kwestii potrzeby i zasad akceptacji w sferze publicznej tożsamości kulturowych, które różnią się od kultury społeczności dominującej w danym państwie (Billig 2008; Habermas 1993; Kymlicka 1995; Offe 2006; Taylor 1992). Znaczenie „walki o uznanie” i „polityki tożsamości” czy też „polityki różnicy" wzrosło przez ostatnie dwa dziesięciolecia XX wieku. Poczucie jedności i ciągłości oraz odmienności od innych kultur ma istotne znaczenie mobilizujące do walki o uznanie grupy przeciwstawiającej się opresji kulturowej, dominacji i nierównemu traktowaniu (Jasińska-Kania 2006). Może być także podstawą dalszych roszczeń w postaci prawa do autonomii kulturalnej czy terytorialnej lub innej formy ochrony. W krajach Europy Środkowo-Wschodniej zagadnienie to nabrało wagi po transformacji ustrojowej lat dziewięćdziesiątych, wraz z pojawieniem się dążeń wielu grup etnicznych do uznania ich odrębności i swoistości kulturowej. Na to, że jedną z konsekwencji transformacji ustrojowej w Europie Środkowo-Wschodniej było upodmiotowienie mniejszości, zwracają uwagę autorzy prawie wszystkich prac dotyczących sytuacji mniejszości w tej części Europy po 1989 roku (Bojar 2000; Cordell 1999; Dudra, Nitschke 2010; Janusz 2011; Kobzarska-Bar 2015; Łodziński 2005).

Upodmiotowienie polityczne mniejszości jest możliwe tylko w systemach demokratycznych. Przełom antykomunistyczny w Europie Środkowo-Wschodniej, który skutkował zmianami prawa krajowego, gwarantującymi wolność słowa, wyznania, stowarzyszania, uczynił z mniejszości aktywnych aktorów społecznych mogących w sferze publicznej swobodnie artykułować swe dążenia. Z przedmiotu polityki etnicznej państwa, wyznaczającej mniejszościom bardzo

o uznanie, a także zagadnienia kultury, tożsamości, emancypacji językowej, miejsce historii w procesie budowania odrębności i ideologii grupowej. Ponadto analizuję tu materiały zastane, etniczną prasę, portale społecznościowe oraz strony internetowe organizacji śląskich. 
ograniczone możliwości działania, zamieniły się one w aktywne podmioty realizujące w sferze publicznej własną politykę tożsamości. Symboliczne momenty zamykające charakterystyczny dla PRL sposób przedmiotowego traktowania mniejszości to, według Sławomira Łodzińskiego (2010), powołanie przez Sejm, w sierpniu 1989 roku, Komisji Mniejszości Narodowych i Etnicznych oraz exposé Tadeusza Mazowieckiego, w którym premier zwrócił uwagę, że Polska jest również ojczyzną mniejszości narodowych.

Zmiany w prawie wewnętrznym krajów byłego bloku wschodniego to nie jedyny czynnik upodmiotowienia politycznego mniejszości. Zbiegły się one bowiem $z$ istotnymi zmianami $\mathrm{w}$ dyskursie na temat praw mniejszości na poziomie międzynarodowym, który pojawił się po drugiej wojnie światowej. Dyskurs ów, początkowo oparty na zasadzie równości wobec prawa i niedyskryminacji, odwołujący się do praw człowieka, chroniący prawa jednostkowe, zaczyna się zmieniać w latach dziewięćdziesiątych XX wieku. Przyznaje członkom mniejszości prawo do aktywnej ochrony ich kultury i tożsamości. „Od 1989 roku pisze Jennifer Jackson Preece (2007, s. 207-208) - dotychczasowa dominująca odpowiedź na różnorodność etniczną w państwie (terytorialna nietykalność łączona $z$ gwarancjami równości jednostek) zaczęła podlegać rosnącej fali krytyki [...]", gdyż obwiniano ją o wzrost liczby przypadków konfliktów etnicznych na całym świecie. Odpowiedzią na tę argumentację było pojawienie się aktów prawa międzynarodowego ${ }^{2}$, w których zawarto szereg praw mniejszości. Chociaż tworzenie mechanizmów ochrony praw mniejszości narodowych zostało zapoczątkowane $\mathrm{w}$ końcu lat czterdziestych XX wieku, to właśnie pod koniec XX wieku prawa mniejszości uzyskały gwarancje instytucjonalne, prawne, jurysdykcyjne i monitorujące. Nie bez znaczenia była także „[...] akceptacja faktu, że prawa mniejszości narodowych stanowią tzw. trzecią generację praw człowieka, obejmującą nie tylko prawa i ochronę praw jednostek, ale także prawa w wymiarze zbiorowym" (Janusz 2011, s. 14-15).

Dyskurs praw mniejszości, w którym odpowiedzią na różnorodność etniczną jest publiczne uznanie różnicy, skutkuje prawem do publicznego wyrażania odrębnej tożsamości „[...] bez obawy przed asymilacją, dyskryminacją czy prześladowaniem" (Preece 2007, s. 208). Co nie mniej istotne, w przyjętej przez ONZ 18 grudnia 1992 r. Deklaracji praw osób należących do mniejszości narodowych lub etnicznych, religijnych $i$ jezykowych, w artykule pierwszym, znalazł się zapis: „Państwa będą chroniły w obrębie ich odnośnych terytoriów istnienie oraz tożsamość narodową lub etniczną, religijną i językową mniejszości, jak również zapewniały warunki służące wspieraniu takiej tożsamości”. Sprawia to, że uzna-

\footnotetext{
${ }^{2}$ Deklaracja praw osób należacych do mniejszości narodowych lub etnicznych, religijnych ijęzykowych przyjęta przez Zgromadzenie Ogólne Narodów Zjednoczonych 18 grudnia 1992 r.; Europejska Karta języków regionalnych lub mniejszościowych, sporządzona w Strasburgu 5 listopada 1992 r.; Europejska Karta języków regionalnych lub mniejszościowych, sporządzona w Strasburgu 5 listopada 1992 r.; Konwencja ramowa o ochronie mniejszości narodowych, sporządzona w Strasburgu 1 lutego 1995 r.
} 
nie istnienia mniejszości na własnym terytorium jest zarazem zobowiązaniem dla państwa. Zapewnienie warunków służących wspieraniu kultury i tożsamości mniejszości wymaga bowiem wydatkowania na ten cel środków $z$ budżetu.

Mimo istnienia dokumentów prawa międzynarodowego regulujących ochronę mniejszości, w których podstawową zasadą jest przyjmowanie tzw. opcji subiektywnej, czyli założenie, że przynależność do mniejszości jest sprawą swobodnego, indywidualnego wyboru jednostki, prawne uznanie przez państwo odrębności kulturowej grup, których członkowie deklarują odmienną tożsamość, nie następuje automatycznie. Brak w prawie międzynarodowym powszechnie obowiązującej definicji mniejszości skutkuje tym, że państwa mają dużą swobodę w zakresie uznawania za mniejszości grup żyjących na ich terytorium. Poszczególne rządy przyjmują bardzo różne rozwiązania, budując system ochrony mniejszości, niejednokrotnie w sposób dość arbitralny wskazują podmioty, które obejmą ochroną, a inne wykluczają z tego systemu. Przyznanie statusu mniejszości wiąże się z tym, że państwo bierze na siebie zobowiązania do aktywnych działań na rzecz wskazanej grupy. Decyzje te mają charakter polityczny. Przyjęte rozwiązania zawsze wymagają zatem porozumienia politycznego między partiami reprezentowanymi w parlamencie. To większość bowiem przyznaje prawa mniejszościom, w ramach demokratycznych procedur stanowiąc odpowiednie prawo.

W Polsce próbą osiągniecia konsensu politycznego co do zakresu ochrony mniejszości i tego, jakie grupy zostaną nią objęte, była praca nad Ustawa o mniejszościach narodowych i etnicznych oraz o języku regionalnym. Przez ponad piętnaście lat była ona przygotowywana przez Komisję Mniejszości Narodowych i Etnicznych działającą w polskim parlamencie. Ta najdłużej w III RP procedowana ustawa jest ważnym dla mniejszości aktem prawnym, jest także bardzo istotnym instrumentem polityki państwa wobec mniejszości. Trudności $z$ osiągnięciem politycznego porozumienia pomiędzy różnymi ugrupowaniami politycznymi, które w kolejnych kadencjach wchodziły do Sejmu i delegowały przedstawicieli do komisji mniejszości zajmującej się przygotowywaniem ustawy, sprawiły, że w pracach nad tym aktem prawnym „[...] można było zauważyć dążenie do coraz bardziej restryktywnego określania mniejszości, które będą objęte ochroną. Widoczne to było w dodawaniu kryteriów dotyczących długości przebywania na terytorium państwa polskiego i stopnia integracji ze społeczeństwem, a także we wprowadzeniu listy grup uznanych oficjalnie za mniejszości" (Łodziński 2004, s. 30). Sposób definiowania mniejszości w ustawie, a także zamknięta ich lista sprawiają, że chroniąc mniejszości w niej wymienione, uznane, może być ona także narzędziem odmawiania tego prawa nowym podmiotom podkreślającym własną odrębność i domagającym się wpisania do ustawy, by skorzystać z ochrony i praw przyznanych na jej mocy mniejszościom. Może uzasadniać odmowę dialogu z grupą, która o uznanie i ochronę zabiega. Jednocześnie pojawienie się ustawy o mniejszościach, której zapisy dają pewne prawa i ułatwiają życie grupom akceptowanym przez państwo, pobudza dą- 
żenia innych grup do uzyskania takiego samego statusu, na co zwraca uwagę Łodziński (2005, s. 165).

Ślązacy są jedną z grup, których liderzy dostrzegli w ustawie szansę na podtrzymanie i rozwój własnej kultury i tożsamości. Według liczby deklaracji zebranych podczas dwóch kolejnych spisów powszechnych (NSP 2002 i 2011) jest to najliczniejsza w Polsce grupa, której członkowie deklarują własną tożsamość. Część z nich walczy o uznanie przez państwo odrębności (językowej bądź etnicznej) i prawną ochronę przewidzianą w ustawie o mniejszościach z 2005 roku. Te dążenia działaczy organizacji śląskich spotykają się ze sprzeciwem różnych aktorów społecznych: władz państwa polskiego oraz części społeczności dominującej, którzy odmawiają uznania Ślązaków za odrębną grupę (pod względem etnicznym/narodowym, traktują tę odrębność jako zróżnicowanie o charakterze regionalnym). Odrębność Ślązaków jest negowana także przez tych przedstawicieli ich własnej społeczności, którzy dokonali innych, możliwych na pograniczu, wyborów tożsamościowych ${ }^{3}$. W związku z tym polityka tożsamości prowadzona przez liderów etnicznych postulujących odrębność własnej grupy jest kierowana zarówno na zewnątrz (państwo polskie, społeczność dominująca), jak i do wewnętrznej opozycji i niezdecydowanych. Pomiędzy zwolennikami różnych opcji tożsamościowych trwa specyficzna „walka o dusze".

Interesuje mnie ta część polityki tożsamości - aktywności śląskich działaczy - która ma na celu prawne uznanie odrębności ich grupy przez państwo polskie. Dyskurs ten toczy się według reguł obowiązujących w polu, które wyznacza uznany przez państwo system ochrony jednostki obejmujący cały zakres praw człowieka - członkowie nie uznanych przez państwo mniejszości korzystają z pełni tych praw (z wolności słowa, równości wobec prawa, prawa do stowarzyszania). Również Ślązacy jako obywatele państwa polskiego mogą - a precyzyjniej: powinni móc - z pełni tych praw korzystać. W kontekście jednej tych zasad - wolności stowarzyszeń — należy analizować między innymi próby rejestracji śląskich organizacji, kolejno: Związku Ludności Narodowości Śląskiej (dalej ZLNŚ) ${ }^{4}$ i Stowarzyszenia Osób Narodowości Śląskiej (dalej SONŚ; organizacja ta według statutu miała zrzeszać osoby, które

\footnotetext{
${ }^{3}$ Na wielowymiarowość tożsamości Ślązaków i podziały tożsamościowe w grupie śląskiej zwraca uwagę wielu badaczy (Sekuła i in. 2012; Nijakowski 2002, 2004; Szmeja 2000, 2013, 2017; Dolińska 2009). W „terenie” spotkałam bardzo różne konfiguracje śląskich tożsamości. Było to złożone kontinuum - od polskich postaw narodowych po niemieckie, często powiązane z odrzuceniem śląskiej odrębności na jakimkolwiek, etnicznym czy narodowym poziomie. Pomiędzy znalazły się deklaracje tożsamości: Polaków-Ślązaków, Ślązaków-Polaków, Ślązaków-obywateli państwa polskiego, Ślązaków (bez dodatkowych dookreśleń) mieszkających na terenie Polski, Ślązaków pochodzenia niemieckiego, Ślązaków-Niemców, Niemców-Ślązaków.

${ }^{4}$ Dyskusja na temat statusu Ślązaków tocząca się od początku lat dziewięćdziesiątych oraz będące częścią procesów emancypacyjnych próby zarejestrowania ZLNŚ są przedmiotem wielu publikacji (Bołdys, Geisler 2008; Łodziński 2004, 2005, 2008; Kwaśniewski 1997; Kranz 1998; Nijakowski 2002, 2004; Gerlich 2002; Sekuła 2009; Sekuła i in. 2012).
} 
w spisie z 2011 roku zadeklarowały narodowość śląską). Obie te próby zakończyły się sądowną odmową wpisania do rejestru i skierowaniem sprawy do Europejskiego Trybunału Praw Człowieka w Strasburgu. Ślązacy nie mogą więc korzystać z prawa do stowarzyszenia gwarantowanego przez prawa człowieka. Ochrona mniejszości opiera się też na prawie do zachowania i ochrony własnej tożsamości, co łączy się z podjęciem przez państwo zobowiązania do prowadzenia aktywnej polityki pozwalającej mniejszościom etniczno-regionalnym, etnicznym czy też narodowym na podtrzymywanie szczególnych charakterystycznych dla danej grupy wartości: języka, kultury, religii itp. Jednak w świetle ustawy z 6 stycznia 2005 r., określającej zobowiązania państwa $\mathrm{w}$ tym zakresie, skorzystanie $\mathrm{z}$ tych praw wymaga wpisania grupy na zamknięta listę podmiotów podlegających ochronie.

Analizowana przeze mnie grupa jest wykluczona z systemu państwowej ochrony. Jednak jej przedstawiciele podejmują wysiłki, by taki status uzyskać. W czasie długotrwałego procesu uchwalania ustawy Ślązacy, zajęci problemem rejestracji ZLNŚ, nie od razu zgłosili potrzebę uwzględnienia ich społeczności w systemie ochrony prawnej (zob. Łodziński 2008, s. 41). Pierwszy list skierowany do Komisji Mniejszości Narodowych i Etnicznych w sprawie wpisania do projektu ustawy „narodowości śląskiej”, autorstwa Jerzego Gorzelika, przewodniczącego Ruchu Autonomii Śląska, pojawił się dopiero po publikacji wyników NSP 2002, w połowie 2003 roku. Komisja nie uwzględniła jednak aspiracji śląskich liderów, stwierdzając brak obiektywnych przesłanek wpisania śląskiej mniejszości etnicznej do ustawy. W latach następnych zmierzający do emancypacji Ślązacy jeszcze kilkakrotnie próbowali uzyskać uznanie prawne. $\mathrm{Z}$ inicjatywy śląskich parlamentarzystów czterokrotnie pojawiły się (w latach $2007,2010,2012,2017)$ poselskie projekty zmiany ustawy, dotyczące wpisania języka śląskiego jako drugiego, obok kaszubskiego, języka regionalnego (pierwszy przygotowała grupa posłów pod przewodnictwem Krzysztofa Szygi z Ruchu Ludowo-Narodowego, dwa następne złożył związany z Platformą Obywatelską Marek Plura, ostatni to inicjatywa posłanki ze Śląska Moniki Rosy). Inny charakter miał złożony w Sejmie w lipcu 2014 roku projekt obywatelski, który zakładał wpisanie Ślązaków do ustawy jako piątej mniejszości etnicznej, działacze śląskich organizacji zebrali pod nim ponad 140 tysięcy podpisów. Był to przejaw mobilizacji etnicznej w okresie okołospisowym. Ponad 800 tysięcy śląskich deklaracji w NSP 2011 pozwoliło zmierzającym do emancypacji śląskim działaczom założyć, że uda się zebrać wymagane 100 tysięcy podpisów. Żadna $z$ tych inicjatyw nie zakończyła się powodzeniem, chociaż kolejny projekt (Nowoczesnej) wpisania języka śląskiego jako drugiego, obok kaszubskiego, języka regionalnego jest jeszcze (marzec 2018) procedowany. Wydaje się, że w obecnej sytuacji politycznej przegłosowanie takiej nowelizacji ustawy jest mało prawdopodobne.

Grupy, którym państwo odmawia uznania, są pobawione podmiotowości ich aspiracje ocenia się jako nieuprawnione, a proponowany przez nie samoopis 
jest odrzucany przez różnych aktorów społecznych: zarówno władze państwa polskiego, część społeczności dominującej, jak i część grupy własnej - tych, którzy wybrali inne możliwe na pograniczu identyfikacje. Śląscy działacze etniczni mogą zatem formułować swe aspiracje w sferze publicznej, podejmować działania $\mathrm{w}$ ramach polityki tożsamości, czyli realizować swą podmiotowość polityczną, do czego potrzebna jest świadomość siebie, własnych celów i interesów, ale szanse na osiągnięcie celów są ograniczone. Często łączy się to $z$ frustracją i poczuciem uprzedmiotowienia. Nie jest to problem tylko grup bezskutecznie walczących o uznanie, ograniczona sprawczość staje się udziałem każdej mniejszości w systemie demokratycznym. Odmowa wpisania do ustawy o mniejszościach powoduje, że grupa nie może korzystać z państwowego systemu ochrony i wsparcia mniejszości.

\section{ŚLĄSKA TOŻSAMOŚĆ W ŚWIETLE WYPOWIEDZI LOKALNYCH DZIAŁACZY}

Odwołując się do narracji zebranych w trakcie badań chciałabym pokazać, jak działacze śląskich organizacji postrzegają niepowodzenia w realizacji swoich aspiracji. Kwestie emancypacji były często poruszane w trakcie rozmów. Wypowiedzi dotyczyły zarówno problemów z rejestracją ZLNŚ i SONŚ, jak i wpisania Ślązaków/godki śląskiej do Ustawy o mniejszościach narodowych i etnicznych oraz o języku regionalnym. Analiza zebranego materiału empirycznego pozwoliła mi na prześledzenie kontekstów, w jakich rozmówcy mówili o problemie uznania przez państwo, jak widzieli konsekwencje jego braku dla własnej grupy, dlaczego walczą o uznanie, jakie metody tej walki preferują, czy wierzą $\mathrm{w}$ powodzenie działań zmierzających do emancypacji. Chciałabym spojrzeć na problem upodmiotowienia mniejszości z perspektywy emic $-z$ perspektywy członków grupy mniejszościowej. Warto bowiem, jak sądzę, postawić pytanie o to, jak brak upodmiotowienia $\mathrm{w}$ relacjach $\mathrm{z}$ państwem widzą liderzy etniczni grupy, która nie jest włączona w system ochrony mniejszości. Jedynej nieuznanej grupy w Polsce, która takie aspiracje przejawia i konsekwentnie od kilkunastu lat o ich realizację zabiega. Wskażę na kilka, wybranych, moim zdaniem najistotniejszych, wątków organizujących w tej kwestii zebrane narracje.

Większość z moich rozmówców uważa, że walka o uznanie przez państwo jest jednym $z$ najważniejszych celów organizacji śląskich. Formalne uznanie narodowości śląskiej zostało wpisane jako jeden z głównych celów Rady Górnośląskiej — organizacji, która powstała w 2012 roku na fali entuzjazmu po ogłoszeniu wyników spisu powszechnego ${ }^{5}$. Rada poparła zarówno starania o reje-

\footnotetext{
${ }^{5} 16$ maja 2012 w Katowicach powołano Radę Górnośląską, skupiającą śląskie organizacje, które adekwatnie do swoich obszarów działania popierają lub akceptują następujące cele: formalne uznanie narodowości śląskiej przez organy Rzeczypospolitej Polskiej; uznanie języka śląskiego za język regionalny; wprowadzenie wiedzy o regionie jako obowiązkowego przedmiotu do szkół podstawowych, gimnazjalnych i ponadgimnazjalnych. Chęć przystąpienia do Rady zgłosiło jedenaście
} 
strację SONŚ, jak i o wpisanie do ustawy o mniejszościach języka śląskiego. Niektóre $z$ wchodzących $w$ jej skład organizacji bardziej lub mniej aktywnie uczestniczyły w zbieraniu podpisów pod obywatelskim projektem ustawy, która zakładałaby zmianę ustawy o mniejszościach przez dopisanie Ślązaków jako piątej, obok Karaimów, Romów, Łemków i Tatarów, mniejszości etnicznej. Oto jedna $z$ charakterystycznych wypowiedzi:

Uznanie prawne, najpierw jezyka ślaskiego, wpisanie do ustawy, w następnej kadencji uznanie etnicznej grupy ślaskiej to najważniejsze zadania stojace przed liderami ślaskimi. $[\mathrm{M} / 65 / 2013]^{6}$

Tylko nieliczni śląscy aktywiści mówili, że uznanie prawne przez państwo polskie i wpisanie do ustawy o mniejszościach jest niepotrzebne. Zwykle tak myślący zwracali uwagę, że te same cele można osiągnąć poprzez uzyskanie autonomii w ramach państwa polskiego. Byli to więc ci, którzy nie ograniczali swoich dążeń do zapewnienia grupie wsparcia w walce na rzecz ochrony i rozwoju śląskiej kultury i tożsamości, lecz preferowali bardziej radykalny program polityczny.

Jak my będziemy mieli autonomię, to my żadnej ustawy potrzebować nie będziemy, bo my wtedy będziemy się rządzić jak chcemy i pieniądze na edukację regionalna, lekcje naszej mowy i cele kulturalne się znajda. I czy my będziemy wtedy mniejszością etniczna, czy nie, to już nie będzie miało znaczenia. [M/60/2012]

Tego typu wypowiedzi potwierdzają słuszność przekonań zwolenników przyznania praw mniejszościom, którzy zakładają, „[...] że mniejszości, które są uznane i popierane przez państwo, a szerzej społeczność międzynarodową, $z$ dużo mniejszym prawdopodobieństwem będą podważały istniejące modele władzy" (Preece 2007, s. 207).

Rozmówcy, którzy uważali, że zmiana statusu grupy jest dla śląskich organizacji istotnym wyzwaniem, w różny sposób uzasadniali konieczność działań na rzecz jego realizacji. Najczęściej pojawiał się argument, że w przypadku wpisania Ślązaków do ustawy (mniej istotne jest to, czy jako grupy posługującej się językiem regionalnym, czy też jako mniejszości etnicznej) będą oni mogli skorzystać z pomocy państwa w podtrzymywaniu i rozwijaniu własnej tożsamości. Moi rozmówcy często sygnalizowali, że ich tożsamość bywa kwestionowana przez przeciwników śląskiej odrębności, jednocześnie dodając, że im samym, przekonanym o swojej śląskości, doskonale wiedzącym, kim są, uznanie przez państwo nie jest potrzebne.

organizacji. Warto zauważyć, że w jej skład weszły zarówno organizacje, które są jednoznacznie kojarzone $z$ walką o uznanie odrębności grupy, jak i te, które zachowują w tej kwestii wyraźną powściągliwość, na przykład Związek Górnośląski, a także te, które działają przede wszystkim na rzecz ochrony i rozwoju „śląskiej godki”. Jesienią 2016 roku do organizacji należało czternaście organizacji.

${ }^{6} \mathrm{~W}$ nawiasach wprowadzam oznaczenia wywiadów, podaję płeć rozmówcy, numer wywiadu i rok jego przeprowadzenia. 
My musimy ciagle udowadniać komuś, kto jest anty, udowadniać, że jesteśmy, a my tak naprawdę, nie musimy, jakby to powiedzieć, że oczekujemy od kogoś, że on uzna nas za narodowość, my po prostu ją mamy, mamy ja, czujemy, więc to nie ma takiego znaczenia. [...] To robi się także, ze względu na te wymierne korzyści, wiążące się z formalizacja statusu, ale jeśli chodzi o indywidualna i wewnętrzna sferę, to ja sam sobie nie muszę udowadniać, że jestem. [M/45/2011]

Liderzy śląscy zwracali uwagę, że wsparcie państwa, które wynika z zapisów ustawy, jest konieczne, ponieważ kultura, godka i tożsamość śląska, poddane wpływom kultury dominującej, są zagrożone. Niektórzy podkreślali, że bez wsparcia państwa kultura śląska nie przetrwa. Większość zakładała, że wsparcie państwa może zahamować procesy zanikania kulturowej odrębności grupy śląskiej. W wypowiedziach często pojawiały się także argumenty, że sytuacja Ślązaków, którzy tak licznie zadeklarowali w dwóch kolejnych spisach narodowość śląską, jest nieporównywalnie gorsza niż innych mniejszości w Polsce. Zdarzały się porównania do sytuacji innych mniejszości europejskich. Niektórzy z badanych podnosili, że wsparcie instytucjonalne jest konieczne, bo chociaż obecnie w grupie śląskiej obserwujemy ożywienie etniczne, podejmuje się wiele działań zmierzających do zachowania i rozwoju zarówno śląskiej kultury, jak i tożsamości, to odbywa się to tylko dzięki społecznemu zaangażowaniu członków grupy. Trudno jest jednak całą działalność opierać na entuzjazmie społecznym, który przecież się wyczerpuje.

Ta ustawa jest dla nas kluczowa, bo jeśli nie będzie edukacji regionalnej, jeśli nie będzie tego jezzyka regionalnego, no to czeka nas spolszczenie, bo te jednostki, które jeszcze czuja ślaskość, wymra, a młodzież już dzisiaj jest tak nawet nie spolszczona a zamerykanizowana, zeuropeizowana. Nie mamy instytucji takich jak Katalończycy czy Baskowie, nawet takich jak inne mniejszości w Polsce [...] Ale jak wszystko pójdzie dobrze i będzie ten język regionalny $w$ ustawie, to będzie to szło $w$ dobrym kierunku. [M/34/2010]

Inny argument o konieczności podejmowania starań o prawne uznanie przez państwo dotyczył zapewnienia swobody działań na rzecz zachowania i rozwoju kultury śląskiej. Jeden z liderów zauważył, że działanie na rzecz grupy czasem spotyka się z przeszkodami ze strony urzędników na Śląsku, którzy widząc niechęć władz centralnych w Warszawie do aspiracji Ślązaków, wolą się im nie narażać. Niektórzy, według badanych, nawet chętnie wsparliby jakieś lokalne inicjatywy śląskich organizacji, ale wolą tego nie robić, bo nie wiedzą, czy wolno. Wolą się nie angażować $\mathrm{w}$ obawie o swoje miejsce pracy. Uznanie sprawiłoby, że takie sytuacje nie miałyby miejsca. Działania Ślązaków zmierzających do emancypacji zyskałyby legitymizację, byłyby dodatkowo umocowane w systemie ochrony mniejszości.

Za podejmowaniem działań zmierzających do prawnego uznania Ślązaków przemawia także, według badanych, chęć dowartościowania grupy śląskiej. Liderzy grup etnicznych, z którymi rozmawiałam, w większości nie mieli wątpliwości, kim są, a także że Ślązacy są odrębna grupą etniczną/narodem, uważali jednak, że dla „zwykłych” Slązaków może to mieć istotne znaczenie. Prawne 
uznanie, zdaniem tak myślących, jest ważne zwłaszcza w przypadku grupy długo dyskryminowanej, której członkowie przez lata nie mieli możliwości uzewnętrzniania swojej tożsamości w sferze publicznej. Wpisanie do ustawy stałoby się źródłem prestiżu. Zakończyłoby także dyskusje na temat tego, kim są Ślązacy. Oddaliłoby sytuację, którą rozmówcy często nazywali „paranoiczną” lub „schizofreniczną" - to, że zarazem są i ich nie ma:

Państwo nie chce przyznać Ślazakom odrębności. Nie ma Ślazaków? To kim ja jestem? Ja nie istnieję, mnie nie ma. Gdybym to tylko byt ja, ale kilkaset tysięcy Ślazaków zadeklarowało w spisie swoja tożsamość $i$ ich też nie ma? [M/67/2013]

Wypowiedzi na temat braku uznania Ślązaków przez państwo bardzo często wskazują na poczucie uprzedmiotowienia i odrzucenia. Mówiono nawet, że brak uznania śląskich aspiracji jest dalszym ciągiem „śląskiej krzywdy” dyskryminacji i wykluczenia. Większość rozmówców podkreślała, że gdy odmawia im się uznania, czują się jak obywatele drugiej kategorii. Co interesujące tego typu opinie odnosiły się zarówno do odmowy wpisania Ślązaków do ustawy - jako mniejszości etnicznej, jak i języka śląskiego jako języka regionalnego. Podobne argumenty pojawiały się $\mathrm{w}$ rozważaniach na temat odmowy zarejestrowania przed laty ZLNŚ czy ostatnio Stowarzyszenia Osób Narodowości Śląskiej. Oto dwie typowe wypowiedzi:

Ślązakiem według mnie jest każdy ten, który się deklaruje do takiej przynależności, decyduje o tym ustawa o spisie powszechnym. A teraz chodzi o to, żeby uporzadkować teraźniejszość, żeby osoby, które zadeklarowaty narodowość ślaska $w$ spisie, a było ich ponad 850 tysięcy, a spis byt przeprowadzony bardzo powierzchownie, miaty prawo do zrzeszania sie, bo prawo do zrzeszania się, to jest jedno $z$ podstawowych praw człowieka $w$ Unii Europejskiej. Kwestia tożsamości ustala się glęboko w sercu, przyznajemy się przed soba kim jesteśmy i osoby, za które decyduje się i nie pozwala im się określić $w$ sposób wolny, sa traktowane jako osoby drugiej kategorii. [M/68/2013]

Natomiast teraz ja się czuję obywatelem drugiej kategorii, mnie nie ma. Tak jak powiedziatem na posiedzeniu tej komisji mniejszości narodowych, które odbyło się tutaj w Katowicach: dla Ślazaków ta sytuacja jest schizofreniczna, bo my możemy być Czechami, Polakami, Żydami, Niemcami, a nie możemy być Ślązakami. Czyli jesteśmy, ale nas nie ma. To jest schizofrenia, to jest idiotyzm. I to jest powiedzenie nam: stój w kacie, bo to prawo nie jest dla ciebie, ono jest dla innych, dla ciebie nie. Czyli co, jestem obywatelem gorszej kategorii. Ja nie chce być obywatelem gorszej kategorii. [M/76/2016]

Istotną część narracji stanowią także rozważania na temat prawa do uznania odrębności Ślązaków w kontekście łamania przez państwo polskie prawa

7 „Śląska krzywda” - według definicji Mariana Grzegorza Gerlicha (2010, s. 113) — to zawarty w pamięci zbiorowej „[...] zespół wyobrażeń, przekonań, ocen opinii, a nawet przesądów, a także związanych z nimi doświadczeń, w tym osobistych, który wyraźnie wskazuje, iż lokalna zbiorowość regionalna była i jest ustawicznie spychana na pozycje społecznie peryferyjne; jest oszukiwana, manipulowana, wykorzystywana, a przestrzeń jej zamieszkania jest poddawana — jak się to niekiedy określa — «kolonialnej» eksploatacji”. 
wewnętrznego (w tym przede wszystkim prawa wolności stowarzyszania) oraz praw, jakie przysługują mniejszościom w świetle prawa międzynarodowego. Postępowanie państwa polskiego często określane jest jako: „łamanie praw człowieka”, „nieprzestrzeganie przepisów prawa międzynarodowego”, „łamanie praw wynikających z podpisanych i ratyfikowanych przez Polskę zobowiązań". Oto dwie charakterystyczne wypowiedzi:

Jeśli $w$ prawie polskim zapisano, to co zapisano, przyznano $w$ ustawie o spisie powszechnym prawo do swobodnego zadeklarowania swojej tożsamości, jeśli jest około miliona ludzi, którzy zadeklarowali to, co zadeklarowali, to do diabła ciężkiego jakim prawem to państwo uniemożliwia usankcjonowanie prawne tej sytuacji. [...] my do tego mamy prawo, bo chcemy, a prawo, to ogólne nie mówi inaczej. Nie mówi, że nie wolno, to urzędnicy tego państwa mówia, że nie wolno. Sąd Najwyższy wydaje orzeczenie sprzeczne z obowiązującym prawem, orzeczenie, $w$ którym widać, że nie do końca doczytali to prawo. Wszędzie gdzie ktoś jest dyskryminowany ze względu na swoje osobiste przekonania, jest dyskryminowany wobec prawa. To jest rzecz nie do pomyślenia w cywilizowanym świecie. [M/59/2012]

Ustawa o mniejszościach, $w$ której nie ma Śląaków, jest sprzeczna z prawem międzynarodowym i całym szeregiem zobowiazań $i$ konwencji, które Polska podpisała, ratyfikowała $i$ które sa elementem systemu prawnego Polski i powinny być przestrzegane, co nie jest na razie czynione. [M/17/2009]

Rozmówcy doskonale znają podstawowe zasady ochrony mniejszości, zarówno polską ustawę o mniejszościach, jak i te akty prawne, które wynikają z przepisów antydyskryminacyjnych. Często odwołują się też do prawa międzynarodowego. Można powiedzieć, że doskonale potrafią dostrzec relację między swoją lokalną sytuacją a uniwersalnym dyskursem ochrony mniejszości. Potwierdza to postawioną przez Erika Eriksena (2014, s. 159) tezę, że polityka tożsamości jest $\mathrm{w}$ istocie fenomenem glokalnym: „[...] jest ograniczona do terytorium i określonej grupy, ale by odnieść sukces, musi się opierać na globalnym dyskursie o kulturze i prawach".

Śląscy działacze podejmują w swoich wypowiedziach także próby wyjaśnienia przyczyny niechęci ze strony państwa polskiego do uznania śląskich aspiracji. Opinie na ten temat są zróżnicowane, chociaż można dostrzec wątek dominujący - że państwo polskie nie chce zgodzić się na uznanie Ślązaków, ponieważ zgodnie $z$ hegemoniczną nacjonalistyczną narracją Ślązacy są częścią narodu polskiego. Tak myślący rozmówcy często charakteryzują Polaków, grupę większościową, jako „skażoną nacjonalizmem” czy „zarażoną nacjonalizmem”:

Powstanie ustawy [rozmówca mówi o projekcie zmiany ustawy, mającym na celu wpisanie do niej Ślązaków - przyp. E.M.] blokuje dominująca w Polsce od okresu romantyzmu ideologia nacjonalistyczna. Jeśli polskie elity stana się europejskie, odejda od nacjonalizmu polskiego, to wtedy będzie można cokolwiek przedsięwziąć w tym względzie. Odejście od ideologii nacjonalistycznej w państwie unitarnym to jest podstawowa rzecz. [M/70/2014]

W zebranych wypowiedziach pojawiają się też inne wyjaśnienia niechęci przedstawicieli polskiej większości do uznania śląskich aspiracji. Według nie- 
których jest to wynik niechęci Polaków do Ślązaków od wielu pokoleń towarzyszącej wzajemnym relacjom, chęci zademonstrowania władzy przez grupę dominującą czy obawy, że uznanie Slązaków przyczyni się do wzmocnienia regionu. Oto jedna $z$ takich wielowątkowych wypowiedzi:

Polacy sa nacjonalistami, to fakt, ale ja bym raczej nie obciązał nacjonalizmu... może lęk, strach, obawa? [...] to jest lęk i zapiekłość. Tak uznaliśmy i tak będzie. To takie przekonania za tym stoja, że Ślazacy to Polacy. Myślę, że też taka zadawniona niechęć do Ślązaków, majaca różnego rodzaju historyczne źródła, manifestująca się dawniej napisami na wagonach „chcesz schabowszczaka, zabij Ślązaka” itd. [...] Tak weglarki z wybrzeża tutaj na Śląsk wracaty, jeszcze przed rewolucja solidarności. [...] Może też obawa, że ten Śląsk stanie się zbyt silny przez to. [M/69/2014]

Część rozmówców przyczynę odmowy zmiany ustawy i uwzględnienia aspiracji Ślązaków widzi w tym, że konieczność aktywnej ochrony przez państwo największej w Polsce, liczącej kilkaset tysięcy mniejszości byłaby bardzo kosztowna:

Tutaj jeśli chodzi o język czy rozszerzenie listy mniejszości etnicznych o Ślazaków, to mo$\dot{z}$ e by $i$ go wpisano, gdyby się nie obawiano, że trzeba będzie wyłożyć dużo pieniędzy na ratowanie tego jezyka, na badania naukowe, na uczenie go w szkołach itd., no tutaj takie kunktatorstwo i sknerstwo nadmierne się odzywa. [M/65/2013]

Większość podnoszących kwestie finansowych konsekwencji zmiany ustawy bardzo krytycznie ocenia takie kalkulacje polskich polityków, zwracając uwagę, że Ślązacy są obywatelami Polski, płacą podatki i mają prawo oczekiwać, że państwo ich wesprze, podobnie jak pozostałe mniej liczne mniejszości.

Nawet jeśli uznanie wiąze się $z$ dotacjami, $z$ wydatkami ze strony panstwa, to ja mówię na to, że Ślask sobie na to zapracowat uczciwie przez dhugie lata i pracuje nadal, do Śląska się nie dopłaca. Jest wiele mitów, na przykład taki, że dopłaca się do górnictwa. [M/65/2013]

Z wypowiedzi na temat odmowy uznania aspiracji Ślązaków wyłania się także rozczarowanie państwem, które traktuje tę społeczność niesprawiedliwie, niektórzy z badanych liderów etnicznych zwracają uwagę, że taka postawa państwa $z$ jednej strony wzmaga mobilizację grupy, a $z$ drugiej - może radykalizować nastroje jej członków. W dyskursie na temat praw mniejszości pojawiły się argumenty, w myśl których upodmiotowienie mniejszości, uznanie jej przez wspólnotę polityczną i włączenie w system ochrony sprawi, że będzie ona $\mathrm{w}$ mniejszym zakresie kwestionować władzę czy zagrażać integralności terytorialnej (Preece 2007, s. 220). Oto dwie z typowych wypowiedzi:

Ja się dziwię Polsce, bo to jest nieracjonalne, to jest konfliktowanie ludzi, to jest doprowadzanie do coraz większej opresji, bo w tym momencie następuje okopywanie się na swoich pozycjach. Zauważa to Pani? Ja to widzę na Ślasku, szczególnie tych działaczy najbardziej skrajnych, nie chcę ich $z$ nazwiska wymieniać. No tu też odzywa się taka reakcja na taka sytuacje, kiedy mówi się, że nas nie ma, że naszego języka nie ma, to rodzi się reakcja na 
niesprawiedliwość. Każda niesprawiedliwość budzi reakcje, a tej niesprawiedliwości było na Ślasku wiele. Ja obawiam się, że jeśli państwo polskie będzie rękami swoich prominentnych działaczy postępować $w$ dalszym ciagu takjak postępuje, to powstana takie rowy, takie doty, że one będą nie do zasypania przez bardzo, bardzo długi czas. [M/59/2012]

Nie ma klimatu politycznego [sprzyjającego uznaniu odrębności Ślązaków — przyp. E.M.], wynik spisu jest tu znaczacy, politykę rozgrywa się w Warszawie. Tego nie będzie. Co może prowadzić do radykalizacji postaw tych, którym się odmawia prawa do tożsamości. [M/65/2013]

Inną kwestią, którą można podjąć na podstawie zebranych narracji oraz wielu rozmów przeprowadzonych w trakcie imprez etnicznych obserwowanych przeze mnie $\mathrm{w}$ różnych okresach badań, jest ocena szans realizacji przez państwo polskie śląskich aspiracji. Można tu wskazać zarówno ogólne zróżnicowanie poglądów, jak i ich zmiany pod wpływem okoliczności zewnętrznych. Miałam wśród rozmówców takich, którzy na początku badań byli umiarkowanymi optymistami i sądzili, że prędzej czy później państwo polskie będzie musiało uznać odrębność Ślązaków i objąć ich ochroną, ale byli i tacy, którzy uważali, że Polska nigdy nie zgodzi się na takie rozwiązanie. Zmiany opinii miały charakter sytuacyjny. Istotnym wydarzeniem, które wygenerowało chwilowy optymizm, było ogłoszenie wyników spisu powszechnego w 20 roku. W okresie „okołospisowym" odnotowałam (Michna 2013) wiele inicjatyw zmierzających do uznania Ślązaków, a także i publicznych wypowiedzi liderów etnicznych, którzy dawali wyraz swojemu optymizmowi. Były one reakcją zarówno na dużą liczbę deklaracji spisowych, jak i decyzję Sądu w Opolu, który zarejestrował Stowarzyszenie Osób Narodowości Śląskiej. Symboliczna w tym względzie jest wypowiedź Jerzego Gorzelika:

Dzisiaj mamy zupetnie inna sytuację... Dzisiaj nie można odmówić człowiekowi wprost prawa samookreślenia, mamy doskonała okazję, by swoją tożsamość kształtować samodzielnie, wręcz niepowtarzalna, jeśli spojrzymy na losy wcześniejszych pokoleń. Tak naprawdę po raz pierwszy Górnoślazacy mogą dokonać swobodnej autorefleksji i powiedzieć, kim sa, kim się czuja i zażadać od państwa, by respektowało te deklaracje... dlatego moje spojrzenie na wspótczesne realia jest spojrzeniem optymistycznym. Uważam, że teraz wszystko zależy od tych, którzy deklaruja swoją odrębność, od ich determinacji, konsekwencji i zdrowego rozsądku. (Spotkanie z Jerzym Gorzelikiem. Trudna historia Górnego Sląska, 14 kwietnia 2011; nagranie w posiadaniu autorki)

Ten optymizm ustąpił jednak miejsca zniechęceniu wraz z kolejnymi niepowodzeniami $\mathrm{w}$ sporze $\mathrm{z}$ państwem. Zarówno odmowa rejestracji stowarzyszenia zrzeszającego osoby narodowości śląskiej, jak i powolne procedowanie, a następnie odrzucenie obywatelskiego projektu ustawy o mniejszościach spowodowało wyraźną zmianę $\mathrm{w}$ ocenie szans realizacji śląskich postulatów. Pojawiła się rezygnacja i brak wiary, że w najbliższym czasie da się zrealizować aspiracje emancypacyjne w toku negocjacji z państwem. Symboliczna jest wy- 
powiedź lidera założonej latem 2015 roku Demokratycznej Unii Regionalistów Śląskich Józefa Porwoła (DURŚ) ${ }^{8}$ :

Zgromadziłem wokół siebie grono ludzi młodych, aktywnych, dla których „walka” o Śląk toczy się zbyt wolno, a właściwie stoi $w$ miejscu $i$ polega na błaganiu władz polskich o jakiekolwiek ustępstwa, stała się bierna, skostniała $i$ schematyczna $w$ swoich działaniach. Ci młodzi ludzie uważaja, że trzeba działać aktywniej, odważniej. Przede wszystkim INACZEJ.

„Inaczej” to, według założycieli DURŚ, przez skoncentrowanie się nie na próbach zmiany obowiązującego w Polsce prawa, ale na pracy u podstaw, tworzeniu śląskich instytucji, rozwijaniu śląskiej kultury, edukacji regionalnej przy wykorzystaniu zasobów grupy, entuzjazmu nauczycieli, społeczników czy przychylności samorządów. To dzięki przychylności samorządów, które mogą na swoim terenie wprowadzić do szkół dodatkowe lekcje edukacji regionalnej, działacze DURŚ rozpoczęli starania o takie lekcje w śląskich miastach. Jako pierwsze pozytywnie zareagowały: Rybnik, Świerklany i Mysłowice. Dotychczas jednak działalność taka zależy od indywidualnego zaangażowania nauczycieli pasjonatów, a DURŚ chciałoby, aby edukacja regionalna była prowadzona w sposób systemowy, a nauczyciele uzyskali wsparcie metodyczne i merytoryczne ${ }^{9}$.

Część rozmówców uważała, że przegrana w sporze $\mathrm{z}$ państwem na poziomie krajowym nie zakończy sporu. Zapowiadali przeniesienie go na poziom międzynarodowy. Ich zdaniem, $w$ odniesieniu do osób, które zadeklarowały w 2011 roku narodowość śląską, zostało naruszone prawo do wolności stowarzyszeń. Po wyczerpaniu drogi prawnej w Polsce, w marcu 2017 roku, SONŚ w likwidacji skierowało sprawę odmowy rejestracji stowarzyszenia do Trybunału Praw Człowieka w Strasburgu. Została ona przyjęta do rozpatrzenia. Założyciele SONŚ przewidywali takie kroki już w styczniu 2012 roku, kiedy Prokuratura Okręgowa w Opolu złożyła apelację do Sądu Okręgowego w Opolu, zaskarżając decyzję sądu pierwszej instancji, który dokonał rejestracji Stowarzyszenia. Jeden z rozmówców tak o tym mówił:

To będzie przedmiotem rozpraw Trybunatu $w$ Strasburgu, na razie nie jest to możliwe, bo $\dot{z} a d n a$ ze spraw sie jeszcze nie uprawomocniła, ale jak wyczerpie się droga prawna $w$ Polsce, jeśli tylko Sąd Najwyższy wyda ostateczne orzeczenie, będzie można iść z tym do Strasburga. Na to czekamy. [M/77/2015]

Sądzono także, że zmiana ustawy o mniejszościach i uzyskanie prawa do ochrony, wynikającego z ustawy przewidującej prawo do zachowania i obrony własnej tożsamości to tylko kwestia czasu. Nadziei na pomyślne rozwiązanie

${ }^{8}$ https://www.facebook.com/demokratyczna.unia.regionalistow.slaskich/?fref=ts [20.07.2015].

${ }_{9}$ DURŚ, Jakie mamy cele? Edukacja. Godka ślasko w szkole, nauka historii regionalnej... (http://www. dursmlodzi.org/nowoczesny-slask/edukacja/ [09.04.2018]). 
sporu upatrywano w naciskach, jakie na państwo polskie może wywrzeć Unia Europejska.

Nie da się takiej polityki neokolonialnej prowadzić bez końca, przy czym w warunkach politycznych, europejskich, tego otoczenia Unii Europejskiej, jakie jest. No my możemy przez jakiś czas nie zauważać różnych ustaw równościowych, ale $w$ pewnym momencie państwo będzie musiato ulec. [M/66/2013]

Nieliczni rozmówcy szansę dla społeczności śląskiej widzą w bardziej uniwersalnych procesach emancypacji etnicznych grup bezpaństwowych i kryzysie państwa narodowego. Wątek kryzysu państwa narodowego, które zostanie zastąpione przez „Europę stu flag”, „Europę regionów” czy „Europę ojczyzn”, pojawia się w narracjach dość często, zwłaszcza w wypowiedziach zwolenników Ruchu Autonomii Śląska:

Proces emancypacji trwa, jest to trend $w$ Europie, państwa narodowe sa już anachronizmem, jak wiemy, wszystko idzie, Europa się jednoczy, ale z drugiej strony wręcz przeciwnie będa się uwypuklać te małe regiony, te mniejsze społeczności będa dawaty o sobie znać. Europa będzie zmierzać do Europy regionów. Będa promowane elementy regionalne. Państwo jest $w$ odwrocie, nie mamy granic, niedtugo nie będziemy mieli własnej waluty, typowego wyznacznika państwa narodowego. [M/41/2011]

Wyniki badań prowadzonych wśród śląskich liderów, którzy dążą do emancypacji etnicznej i uzyskania statusu odrębnej, uznanej przez prawo mniejszości etnicznej, wskazują, że analizowana społeczność znajduje się w złożonym położeniu - międ zy polityczną podmiotowością a poczuciem uprzedmiotowienia. Zmiany ustrojowe pozwoliły bowiem na swobodne wyrażanie własnej tożsamości w sferze publicznej oraz podejmowanie działań zmierzających do zachowania i rozwoju tożsamości. Korzystając z zasad przewidzianych przez demokratyczne państwo prawa, Ślązacy starają się o uznanie ich odrębności i zapewnienie prawnej ochrony. Odmowę rejestracji SONŚ moi rozmówcy uznali za ograniczenie przez państwo polskie ich prawa do wolności stowarzyszania się i naruszenie zasad zapisanych w dokumentach prawa międzynarodowego ratyfikowanych przez Polskę. Podobnie jak w przypadku odmowy rejestracji przed laty ZLNŚ, decyzję o odmowie rejestracji SONŚ skierowali do Trybunału Praw Człowieka w Strasburgu. Starając się o prawną ochronę własnej kultury i tożsamości liderzy śląskich organizacji prowadzą politykę tożsamości w polu zdeterminowanym przez główny dokument wyznaczający ramy ochrony mniejszości w Polsce, jakim jest Ustawa o mniejszościach narodowych $i$ etnicznych oraz o języku regionalnym z 6 stycznia 2005 roku, która nie tylko określa zakres ochrony mniejszości i przyznanych im praw, definiuje mniejszość narodową i etniczną, ale także zawiera ich zamkniętą listę. Aby zatem zmienić swój status prawny i móc skorzystać z ochrony własnej kultury i tożsamości, działacze śląscy muszą doprowadzić 
do zmiany ustawy. Dążąc do emancypacji grupy, odwołują się do globalnego dyskursu praw człowieka, sięgają po jego argumenty w sporze z państwem. Dyskurs ten każe im widzieć własne roszczenia jako uprawnione. Państwo polskie jednak konsekwentnie uznaje Ślązaków za grupę etnograficzną narodu polskiego i odmawia zmiany jej statusu. Jak pokazuje zebrany materiał empiryczny, odmowa uznania proponowanego przez grupę samoopisu, prawa do zrzeszania osób, które tożsamość śląską w ostatnim spisie zadeklarowały - odmowa wpisania do ustawy gwarantującej grupie wsparcie finansowe i instytucjonalne państwa - wywołuje poczucie krzywdy, uprzedmiotowienia, jest dla śląskich aktywistów powodem frustracji i zniechęcenia, a także wyznacza negatywny stosunek do państwa polskiego. Wiele wypowiedzi ma charakter emocjonalny, moi rozmówcy widzą w działaniach władzy łamanie ich praw do samookreślenia, wyraz traktowania ich jako obywateli drugiej kategorii.

\section{BIBLIOGRAFIA}

Billig Michael, 2008, Banalny nacjonalizm, tłum. Maciej Sekerdej, Znak, Kraków.

Bojar Hanna, 2000, Mniejszości społeczne w państwie i społeczeństwie III Rzeczypospolitej Polskiej, FUNNA, Wrocław.

Bołdys Patrycja, Geisler Robert, 2008, Ślaski neotrybalizm — od konfliktu do nowoczesnego ruchu regionalnego. Ewolucja Ruchu Autonomii Ślaska i jego ideologii, w: Andrzej Sakson (red.), Ślazacy, Kaszubi Mazurzy i Warmiacy — między polskościa a niemieckościa, Instytut Zachodni, Poznań.

Cordell Karl, 1999, Ethnicity and Democratisation in the New Europe, Routledge, London-New York.

Dolińska Kamilla, 2009, Potoczny i ideologiczny poziom doświadczania ślaskości. Ślązacy w poszukiwaniu odrębności?, Wydawnictwo Uniwersytetu Wrocławskiego, Wrocław.

Dudra Stefan, Nitschke Bernadetta, 2010, Mniejszości narodowe i etniczne w Polsce po II wojnie światowej, Nomos, Kraków.

Eriksen Thomas Hylland, 2014, Globalization, Bloomsbury, London.

Gerlich Marian Grzegorz, 1994, „Ślaska krzywda” — przejaw zbiorowego poczucia poniżenia górnoślaskiej ludności rodzimej (okres międzywojnia), „Etnografia Polska”, t. 38, z. 1-2.

Gerlich Marian Grzegorz, 1995, Korzenie „śląskiej krzywdy”, „Śląsk”, grudzień, nr 2, s. 28-31.

Gerlich Marian Grzegorz, 2002, Powotywanie narodu ślaskiego. Od Katowic do Strasburga - wyboista droga do rejestracji Związku Ludności Narodowości Ślaskiej, „Etnografia Polska”, nr 1-2.

Habermas Jürgen, 1993, Obywatelstwo a tożsamość narodowa. Rozważania nad przyszłościa Europy, tłum. Barbara Markiewicz, Wydawnictwo Instytutu Filozofii i Socjologii PAN, Warszawa.

Janusz Grzegorz, 2011, Ochrona praw mniejszości narodowych w Europie, Wydawnictwo Uniwersytetu Marii Curie-Skłodowskiej, Lublin.

Jasińska-Kania Aleksandra, 2006, Teorie Tożsamości i różnicy. Wstęp, w: Aleksandra Jasińska-Kania, Lech M. Nijakowski, Jerzy Szacki, Marek Ziółkowski (red.), Współczesne teorie socjologiczne, Scholar, Warszawa.

Kobzarska-Bar Barbara, 2015, Podmiotowość polityczna mniejszości a konflikt etniczny. Mniejszość niemiecka w Polsce i mniejszość polska na Litwie w świetle teorii mobilizacji zasobów, „Wschodnioznawstwo”, nr 1, s. 221-238.

Kranz Jerzy, 1998, Mniejszość narodowa Ślązaków, „Sprawy Międzynarodowe”, nr 4. 
Kwaśniewski Krzysztof, 1997, Czy istnieje narodowość śląska?, „Sprawy Narodowościowe. Seria Nowa", z. 1.

Kymlicka Will (red.), 1995, The Rights of Minority Cultures, Oxford University Press, Oxford.

Łodziński Sławomir, 2004, Narodowy Spis Powszechny (2002) a problemy uznawania za „mniejszość narodowa (etniczna)”. Łemkowie, Ślazacy, Kaszubi, „Przegląd Polonijny”, z. 3.

Łodziński Sławomir, 2005, Równość i różnica. Mniejszości narodowe w porządku demokratycznym w Polsce po 1989 roku, Scholar, Warszawa.

Łodziński Sławomir, 2008, Instytucje i tożsamość etniczna. Ślazacy i Kaszubi wobec Narodowego Spisu Powszechnego Ludności (2002 r.) i Ustawy o mniejszościach (2005 r.), w: Andrzej Sakson (red.), Ślazacy, Kaszubi Mazurzy i Warmiacy - między polskością a niemieckością, Instytut Zachodni, Poznań.

Łodziński Sławomir, 2010, Polityka wobec mniejszości narodowych i etnicznych $w$ Polsce $w$ latach 19455-2008, w: Stefan Dudra, Bernadetta Nitchke (red.), Mniejszości narodowe i etniczne w Polsce po II wojnie światowej, Nomos, Kraków.

Michna Ewa, 2013, Narodowy Spis Powszechny Ludności i Mieszkań w 2011 r. i jego wykorzystanie w polityce tożsamości i walce o uznanie: casus Ślazaków, „Studia Migracyjne. Przegląd Polonijny”, t. 39, nr 2.

Nijakowski Lech M., 2002, Dyskursy o Ślasku. Kształtowanie ślaskiej tożsamości regionalnej $w$ dyskursie publicznym, Wydawnictwo Uniwersytetu Opolskiego, Warszawa.

Nijakowski Lech M. (red.), 2004, Nadciagają Ślazacy, czy istnieje narodowość ślaska?, Scholar, Warszawa.

Offe Claus, 2006. „Homogeniczność” $i$ demokracja konstytucyjna. Konflikty tożsamości a prawa grupowe, w: Aleksandra Jasińska-Kania, Lech M. Nijakowski, Jerzy Szacki, Marek Ziółkowski (red.), Wspótczesne teorie socjologiczne, Scholar, Warszawa.

Preece Jennifer Jackson, 2007, Prawa mniejszości, tłum. Małgorzata Stolarska, Wydawnictwo Sic!, Warszawa.

Sekuła Elżbieta Anna, 2009, Po co Ślazakom potrzebny jest naród? Niebezpieczne związki między autonomia a nacjonalizmem, Wydawnictwa Akademickie i Profesjonalne, Warszawa.

Sekuła Elżbieta Anna, Jałowiecki Bohdan, Majewski Piotr, Żelazny Walter, 2012, Być narodem? Ślazacy o Ślasku, Scholar, Warszawa.

Szmeja Maria, 2000, Niemcy? Polacy? Ślązacy! Rodzimi mieszkańcy Opolszczyzny w świetle badan socjologicznych, Universitas, Kraków.

Szmeja Maria, 2013, Czy zmiana identyfikacji? Ślazzacy we współczesnym społeczeństwie polskim, „Przegląd Polonijny", z. 1(147).

Szmeja Maria, 2017, Ślask bez zmian? Ludzie, kultura i społeczność Ślaska w perspektywie postkolonialnej, Nomos, Kraków

Taylor Charles, 1992, Multiculturalism and "The Politics of Recognition", Princeton University Press, Princeton, New Jersey.

Zarycki Tomasz, 2005, Uciemiężona forpoczta Zachodu. Wiktymizacja i okcydentalizacja we wspótczesnym polskim dyskursie regionalnym, „Kultura i Społeczeństwo”, nr 2.

Deklaracja praw osób należących do mniejszości narodowych lub etnicznych, religijnych i językowych przyjęta przez Zgromadzenie Ogólne Narodów Zjednoczonych w dniu 18 grudnia 1992 (http://www. spoleczenstwoobywatelskie.gov.pl/sites/default/files/deklaracja_praw_osob_nalezacych_do_m niejszosci.pdf [17.02.26]).

Ustawa z dnia 6 stycznia 2005 r. o mniejszościach narodowych i etnicznych oraz o języku regionalnym, Dz.U. RP nr 17, poz. 141. 


\title{
SILESIANS BETWEEN POLITICAL SUBJECTIVITY AND THE SENSE OF OBJECTIFICATION
}

\author{
Ewa Michna \\ (Jagiellonian University)
}

\section{Summary}

This article concerns identity politics in the broader, theoretical perspective. The author discusses the activities of Silesian activists who are striving to have the Polish state formally recognize their group's separateness. Their activities are subject to the rules arising from the national system for the protection of minorities, which rests on two ideas: the principle of non-discrimination in the treatment of all citizens, and the right to preserve and protect one's own identity (with the active aid of the state in this regard). In Poland, obtaining the right to protection requires the state's legal recognition of a group, that is, the group must be inscribed in the Law on National and Ethnic Minorities and Regional Languages. The Silesians have been unsuccessfully attempting to obtain such recognition for over a dozen years. The author, on the basis of her own research, addresses the question of how non-inclusion in the system for protecting minorities is seen by leaders of an excluded ethnic group.

\section{Key words / słowa kluczowe}

Silesians / Ślązacy, identity politics / polityka tożsamości, majority-minority relations / relacje mniejszość-większość, protection of a minority / ochrona mniejszości, ethnicity / etniczność 